\title{
On the comparisons of tropical relative humidity in the lower and middle troposphere among COSMIC radio occultations and MERRA and ECMWF data sets
}

\author{
P. Vergados, A. J. Mannucci, C. O. Ao, J. H. Jiang, and H. Su \\ Jet Propulsion Laboratory, California Institute of Technology, Pasadena, California, USA \\ Correspondence to: P. Vergados (panagiotis.vergados@jpl.nasa.gov) \\ Received: 1 November 2014 - Published in Atmos. Meas. Tech. Discuss.: 15 January 2015 \\ Revised: 12 March 2015 - Accepted: 18 March 2015 - Published: 17 April 2015
}

\begin{abstract}
The spatial variability of the tropical tropospheric relative humidity $(\mathrm{RH})$ throughout the vertical extent of the troposphere is examined using Global Positioning System Radio Occultation (GPSRO) observations from the Constellation Observing System for Meteorology, Ionosphere, and Climate (COSMIC) mission. These high vertical resolution observations capture the detailed structure and moisture budget of the Hadley Cell circulation. We compare the COSMIC observations with the European Center for Medium-range Weather Forecast (ECMWF) Reanalysis Interim (ERA-Interim) and the Modern-Era Retrospective analysis for Research and Applications (MERRA) climatologies. Qualitatively, the spatial pattern of RH in all data sets matches up remarkably well, capturing distinct features of the general circulation. However, RH discrepancies exist between ERA-Interim and COSMIC data sets that are noticeable across the tropical boundary layer. Specifically, ERA-Interim shows a drier Intertropical Convergence Zone (ITCZ) by $15-20 \%$ compared to both COSMIC and MERRA data sets, but this difference decreases with altitude. Unlike ECMWF, MERRA shows an excellent agreement with the COSMIC observations except above $400 \mathrm{hPa}$, where GPSRO observations capture drier air by $5-10 \%$. RH climatologies were also used to evaluate intraseasonal variability. The results indicate that the tropical middle troposphere at $\pm 5-25^{\circ}$ is most sensitive to seasonal variations. COSMIC and MERRA data sets capture the same magnitude of the seasonal variability, but ERA-Interim shows a weaker seasonal fluctuation up to $10 \%$ in the middle troposphere inside the dry air subsidence regions of the Hadley Cell. Over the ITCZ, RH varies by maximum $9 \%$ between winter and summer.
\end{abstract}

\section{Introduction}

Model simulations, reanalyses data sets, and satellite observations show large discrepancies of the global humidity climatology. Tian et al. (2013) showed that the tropical boundary layer in the Modern-Era Retrospective Analysis for Research and Applications (MERRA) is $10 \%$ drier than the Atmospheric Infrared Sounder (AIRS) observations. Yet, above $700 \mathrm{hPa}$ MERRA shows a wetter environment than AIRS by more than $20 \%$. These values are recorded over the Intertropical Convergence Zone (ITCZ) - a region characterized by deep convection and persistent cloud coverage. They also reported that a composite of 16 climate models from the Coupled Model Intercomparison Project Phase 5 (CMIP5) archive is $15 \%$ drier than the AIRS observations below $600 \mathrm{hPa}$ but $30 \%$ wetter in the middle and upper troposphere.

Jiang et al. (2012) showed that CMIP5 models are twice as moist as the AIRS and the Microwave Limb Sounder (MLS) observations in the upper troposphere, but in the middle troposphere CMIP5 models are moister than AIRS and MLS by $10 \%$. Chuang et al. (2010) reported large differences in the interannual anomaly of the upper troposphere humidity among CMIP5 models, European Center for Mediumrange Weather Forecast (ECMWF) data sets, and AIRS observations over deep convective regions. Chen et al. (2008) showed disparities in the humidity field in ERA-40 and National Centers for Environmental Prediction (NCEP) reanalyses - also documented by Huang et al. (2005), who had found inconsistent interannual variabilities of the tropical humidity among the ERA-40 and the NCEP reanalyses with respect to the Geophysical Fluid Dynamics Labo- 
ratory AM2 model and the High-resolution Infrared Radiation Sounder (HIRS) observations. John and Soden (2007) documented that CMIP3 models show a PBL that is $25 \%$ drier than AIRS and ECMWF data sets, while they reported a significant moist bias in the free troposphere of up to $100 \%$. Such discrepancies lead to undesirable inconsistencies among models, reanalyses, and remote sensing platforms that have greater repercussions in weather forecasting and climate research and their future projections.

A viable path towards improving the current models, reanalyses, and satellite observational skills in capturing the water vapor's dynamics is to have observations that are as independent from weather and climate models and reanalyses as possible. Despite the advancements in space-based remote sensing, caveats still exist even in the satellite records. In particular, clouds may contaminate infrared (IR)-based observing platforms (e.g., AIRS; Fetzer et al., 2006), while modeling errors of the Earth's limb radiances can impact microwave (MW) sounder retrievals (e.g., MLS; Read et al., 2007), introducing biases in the derived humidity climatologies. Both IR and MW sounders have a coarse vertical resolution (e.g., $2-3 \mathrm{~km}$ ) that is inadequate to resolve the detailed vertical structure of water vapor. Lin et al. (2012) and Boyle and Klein (2010) emphasized that having vertically resolved high spatial resolution atmospheric data makes model convection parameterization more responsive to environmental conditions, while Tompkins and Emanuel (2000) quantified the required vertical resolution to properly characterize the humidity climatology to be $25 \mathrm{hPa}$ (or $\sim 100 \mathrm{~m}$ ). Groundbased in situ measurements (e.g., radiosondes, lidars, and radars) are limited over land and lacking information over oceanic regions, while different reanalyses exhibit considerable differences (even after the assimilation of satellite observations).

There is an increased need for an improved definition of the Earth's global humidity climatology that could help discern current discrepancies in models, reanalyses, and observations. Carlowicz (1996) emphasized that better tools are needed to measure water vapor, suggesting the Global Positioning System Radio Occultation (GPSRO) technique as a strong candidate due to its unique characteristics that are valuable to atmospheric monitoring: all-weather sensing, high vertical resolution (100-200 m; Kursinski et al., 2000; Schmidt et al., 2005), high specific humidity accuracy $\left(<1.0 \mathrm{~g} \mathrm{~kg}^{-1}\right)$, high temperature accuracy $(<0.5 \mathrm{~K})$, and sampling of the full diurnal cycle. For these reasons, we propose constraining past and present-day humidity climatologies by using GPSRO observations. Together with state-of-the-art reanalyses, GPSRO data sets have the potential to greatly improve the current global humidity climatology and its related feedbacks.

In 1995, the GPS/METeorology (GPS/MET) radio occultation (RO) experiment demonstrated how atmospheric refractivity, temperature, and water vapor profiles are obtained
(Rocken et al., 1997). Since then, numerous RO missions ${ }^{1}$ have flown, and currently fly, exploring the capabilities of the RO technique as a complementary data set to the existing data records. The National Research Council Decadal Survey for Earth Science (NRC, 2007) identified radio occultations as a critical measurement for weather and climate observations, highlighting the fact that all of the appropriate low Earth orbit missions should include a GPS receiver to augment operational measurements of temperature and water vapor. Kursinski et al. (1997), Rocken et al. (1997), Kursinski and Hajj (2001), and Colard and Healey (2003) described the retrieval process of humidity profiles from GPSRO observations. Steiner et al. (1999), Gorbunov and Kornblueh (2001), Divakarla et al. (2006), Ho et al. (2007), Chou et al. (2009), Ho et al. (2010), Sun et al. (2010), Gorbunov et al. (2011), Kishore et al. (2011), Wang et al. (2013), and Vergados et al. (2014) validated the GPSRO-based humidity retrievals against reanalyses, radiosondes, and satellite observations, while recently Kursinski and Gebhardt (2014) reported an innovative technique to further reduce and eliminate retrieval biases in the middle-troposphere humidity products.

The overarching objective of this study is to use the GPSRO data sets to characterize the tropical humidity climatology. We will conduct our analysis over a seasonal timescale. This is because the spatial patterns and the seasonal cycle of relative humidity $(\mathrm{RH})$ are fundamental energy balance quantities and play a critical role in climate research. We will compare the GPSRO observations against ECMWF and MERRA data sets to observationally constrain the strength of seasonal variability in the reanalyses. Our effort on constraining humidity exemplifies an end-to-end application of evaluating and validating the complementarity of GPSRO observations, while gaining new insights about the representation of moist convection that is not properly captured by the reanalyses (e.g., Dai, 2006; Holloway and Neelin, 2009; Hannay et al., 2009; Frenkel et al., 2012) and helping to provide guidelines for future model improvements.

The novelty of our study lies in the fact that we are the first to compare GPSRO observations with MERRA data sets. The motivation for this study comes from the fact that MERRA does not assimilate GPSRO products (unlike ECMWF), providing an additional step towards assessing the GPSRO humidity profiles. Such a study will also provide further insight about the water vapor dynamics as well as help us constrain current model physics. We attempt to properly characterize the GPSRO-based humidity climatology and place it into perspective with current reanalyses in order to explore its potential for advancing our knowledge on tropical weather and climate research. This paper is or-

\footnotetext{
${ }^{1}$ Challenging Mini-Satellite Payload (CHAMP); Constellation Observing System for Meteorology, Ionosphere, and Climate (COSMIC); Meteorological Operational Polar Satellite A (MetOP-A); Gravity Recovery and Climate Experiment (GRACE); TerraSAR-X.
} 
ganized as follows. Section 2 describes the data sets, while Sect. 3 presents and discusses our results. Section 4 provides a summary of our current research and our concluding remarks, followed by recommendations on future directions.

\section{Data sets}

We analyze RH climatologies from GPSRO observations and ECMWF and MERRA data sets during winter 2007-2009 (December-January-February, DJF) and summer 20072009 (June-July-August, JJA). We focus on the tropics and subtropics $\left(40^{\circ} \mathrm{S}-40^{\circ} \mathrm{N}\right)$ around the globe $\left(180^{\circ} \mathrm{W}-180^{\circ} \mathrm{E}\right)$, because this latitudinal belt contains the majority of water vapor and has been identified to be the most sensitive to climate change.

\subsection{Constellation observing system for meteorology, ionosphere, and climate}

COSMIC is a constellation of six microsatellites placed in near-circular low Earth orbit at $\sim 800 \mathrm{~km}$ altitude (Schreiner et al., 2007). They record the phase and amplitude of dual frequency $L$-band GPS signals $\left(f_{1}=1.57542 \mathrm{GHz}\right.$; $f_{2}=1.22760 \mathrm{GHz}$ ) as a function of time. The time derivative of these phase measurements provides an estimate of the Doppler shift of the GPS signals due to the presence of the Earth's atmosphere (provided ionospheric contributions have been removed from the observations). Together with COSMIC and GPS orbital information (position and velocity vectors), the Doppler is used to estimate the bending of the GPS signals from which the refractivity is extracted (Ho et al., 2009). The relative motion of the COSMIC and GPS satellite pair allows for the vertical scanning of the atmosphere and the retrieval of vertical profiles of atmospheric refractivity, which in turn contains temperature and humidity information. The GPS $L$-band frequencies have low sensitivity to clouds and precipitation, making them especially useful over cloudy regions.

Here, we use the forward refractivity operator (e.g., Smith and Weintraub, 1953; Kursinski et al., 1997; Hajj et al., 2002; Heise et al., 2006) to compute the water vapor pressure:

$N=77.6 \frac{P}{T}+3.73 \cdot 10^{5} \frac{e}{T^{2}} \Longleftrightarrow e=\frac{1}{3.73 \cdot 10^{5}}$

$\left(N T^{2}-77.6 P T\right)$,

where $N$ (unitless) is the COSMIC refractivity, $P$ (mbar) is the pressure, $T(\mathrm{~K})$ is the ECMWF temperature, and $e$ (mbar) is the GPSRO-derived water vapor pressure. The refractivity data are obtained from the "wetPrf" COSMIC data files with a vertical resolution of $100 \mathrm{~m}$ in the troposphere, while the temperature profiles are provided by ECMWF analysis. We decide to use this method, instead of the "wetPrf" profile humidity that is the product of a variational assimilation using a priori atmospheric state, because we would like to be as in- dependent of a priori humidity information and its associated errors as possible. Given the COSMIC refractivity accuracy of $\sim 1 \%$ at $2 \mathrm{~km}$ and $\sim 0.2 \%$ at $6-8 \mathrm{~km}$ (Schreiner et al., 2007), the major error in the humidity retrieval is the a priori temperature information and its error characteristics. Thus, given robust temperature retrievals from independent data sets, we can solve for the humidity while meticulously quantifying the uncertainties arising from the temperature profiles (cf. Sect. 3.3). Because Eq. (1) requires that both the GPSRO and the ECMWF data sets be reported at the same pressure levels, we interpolate the ECMWF temperature profiles into the vertical grid of the GPSRO profiles using linear interpolation.

Rienecker et al. (2011) report that MERRA follows closely the ECMWF temperature variability at monthly and seasonal timescales, especially in the lower and middle troposphere that is well constrained by radiosonde observations. In particular, at $500 \mathrm{hPa}$ both analyses show indistinguishable interannual variability; MERRA exhibits only at $200 \mathrm{hPa}$ a bias of the order of $0.5 \mathrm{~K}$, while ECMWF shows half of that. Therefore, there is no advantage to selecting one analysis over another given that our own analysis treats multi-year climatology data sets. Hence, in Sect. 3.3 we performed a sensitivity analysis of the retrieved GPSRO relative humidity products on temperature uncertainty by introducing a $\pm 1.0 \mathrm{~K}$ temperature error throughout the vertical extent of the troposphere. These results serve to qualitatively and quantitatively guide the reader through the structural differences of the GPSRO relative humidity products. Additionally, ECMWF is the analysis routinely used by numerous researchers and by the COSMIC Data Analysis and Archive Center (CDAAC) for the retrieval of the GPSRO water vapor pressure profiles.

The CDAAC provides both the COSMIC and the ERAInterim profiles (cf. cdaac-www.cosmic.ucar.edu/cdaac/). We use the water vapor pressure derived from Eq. (1) to estimate RH with respect to liquid water, which is the World Meteorological Organization (WMO) standard measurement, using

$\mathrm{RH}=\frac{e}{e_{\mathrm{s}}} \times 100 \%$,

$e_{\mathrm{s}}=6.112 \cdot \exp \left(\frac{17.62 \cdot T}{T+243.12}\right)$,

where $e_{\mathrm{S}}(\mathrm{hPa})$ is the saturation water vapor pressure and $T\left({ }^{\circ} \mathrm{C}\right)$ is the temperature. This formula is from the WMO Guide to Meteorological Instruments and Methods of Observation (CIMO Guide, WMO No. 8) formulation (WMO, 2008).

\subsection{MERRA v5.2.0}

From MERRA (v5.2.0) (Rienecker et al., 2011), we use relative humidity estimations with respect to liquid water available at the GES DISC Giovanni Interactive Visualization and Analysis. The data can be down- 
loaded from http://gdata1.sci.gsfc.nasa.gov/daac-bin/G3/gui. cgi?instance_id=MERRA_MONTH_3-D and are given in a $1.25^{\circ} \times 1.25^{\circ}$ latitude-longitude grid and 25 vertical pressure levels in the troposphere. The vertical resolution between the surface and up to $700 \mathrm{hPa}$ is $25 \mathrm{hPa}$, while between $700 \mathrm{hPa}$ and $300 \mathrm{hPa}$ the vertical resolution becomes coarser, decreasing to $50 \mathrm{hPa}$.

MERRA is a NASA analysis based solely on assimilation of satellite observations using Goddard's Earth Observing System (GOES) version 5.2.0 Data Assimilation System (Rienecker et al., 2008). It primarily assimilates radiances from the AIRS instrument, the Advanced Television and Infrared Observatory Spacecraft Operational Vertical Sounder (ATOVS), and the Special Sensor Microwave Imager (SSM/I). We refer the reader to Fig. 4 in Rienecker et al. (2011) for a detailed description of the rest of the data sets currently being assimilated. The major advantage of using MERRA data sets in this study is that MERRA does not assimilate GPSRO products.

\subsection{European Center for Medium-range Weather Forecast Reanalysis Interim}

ERA-Interim is one of the most advanced global atmospheric models simulating the state of the atmosphere with accuracy similar to what is theoretically possible (Simmons and Hollingsworth, 2002) using a 4D-Var method (Simmons et al., 2005). Primarily, it assimilates radiosonde humidities and AIRS radiances and, as of 1 November 2006, GPSRO bending angle profiles (Dee et al., 2011). As a global analysis grid, it can be interpolated to a desired location and its accuracy is based on the error characteristics of the assimilated data. Currently, ERA-Interim uses the T255 grid scheme that translates to approximately $80 \mathrm{~km}$ horizontal resolution and uses 37 vertical pressure levels between $1000 \mathrm{hPa}$ and $1 \mathrm{hPa}$, with 11 pressure levels available in the troposphere. The ERAInterim profiles are obtained by the CDAAC database.

\section{Results}

\subsection{Diagnosing the spatial distribution of relative humidity using GPSRO observations}

Figure 1 presents the 3-year zonal-mean RH climatology over the tropics and subtropics $\left( \pm 40^{\circ}\right)$ during summer and winter as a function of pressure level and latitude. A direct comparison among all data sets indicates that the spatial distribution patterns of the RH fields match up remarkably well. All data sets display an upward current of moist air from the lower to the upper troposphere around the equatorial latitudes, which coincides with the ITCZ location. In the middle troposphere, we identify regions of low RH fields centered at $\pm 20-25^{\circ}$ between 600 and $500 \mathrm{hPa}$ in both hemispheres, representing areas of dry air subsidence. All these are well-
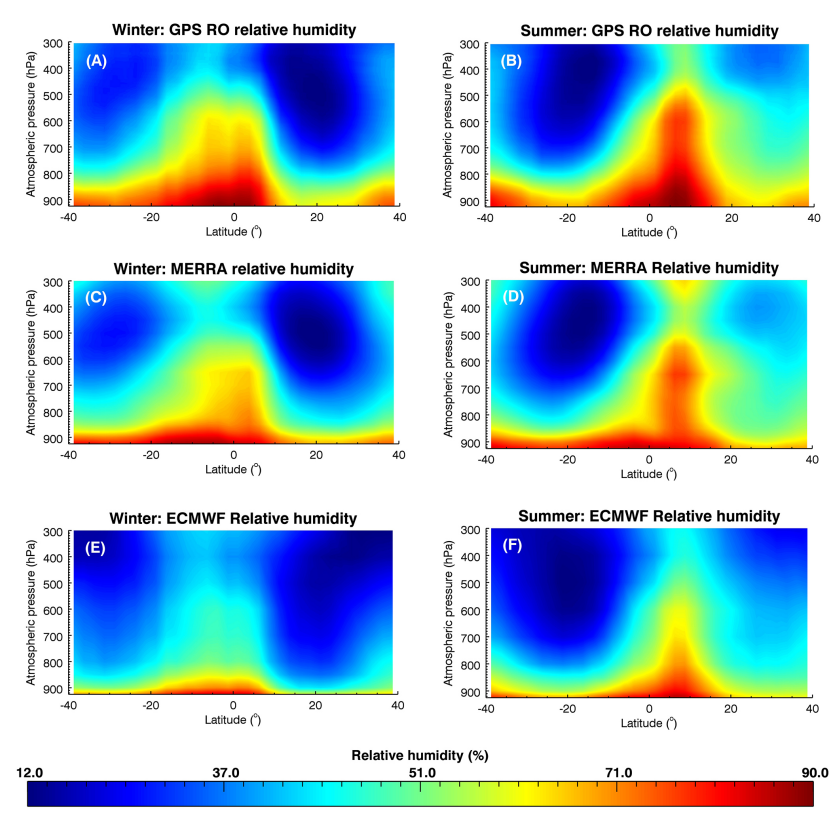

Figure 1. Pressure-latitude cross sections of relative humidity during winter (DJF; left column) and summer (JJA; right column) seasons averaged over the 2007-2009 period using GPSRO (a and b) observations and MERRA (c and d) and ECMWF (e and f) reanalyses.

documented features of the Hadley Cell circulation, which are also captured by GPSRO data.

Despite the qualitative agreement among the data sets, we are interested in the magnitude of the RH differences with respect to one another, as we want to (a) investigate the GPSRO products and (b) examine the reanalyses' representativeness of tropical moist convection. To the best of our knowledge, this is the first time that GPSRO observations are used to study the 3-D spatial patterns of the moist thermodynamic budget of the Hadley Cell circulation (that encompasses the ITCZ) and place an observational constraint on the reanalyses data.

\subsubsection{Comparing GPSRO observations with ECMWF reanalysis}

GPSRO observations indicate that the boundary layer (900$700 \mathrm{hPa}$ ) over the ITCZ (and in all other latitudes) is systematically moister than ECMWF (cf. Figs. 1, 2). The RH differences are the largest around the equatorial belt, and their magnitude varies with pressure level and geographic location. During winter, we report a maximum absolute difference of $\sim 10 \%$ at $900 \mathrm{hPa}$ that grows to $\sim 20 \%$ at $700 \mathrm{hPa}$, while during summer these differences are smaller. In the winter middle troposphere (700-500 hPa), GPSRO shows again a wetter ITCZ than ECMWF by $5-15 \%$, but at higher latitudes both GPSRO and ECMWF agree remarkably well because the computed RH differences fall within the GPSRO 

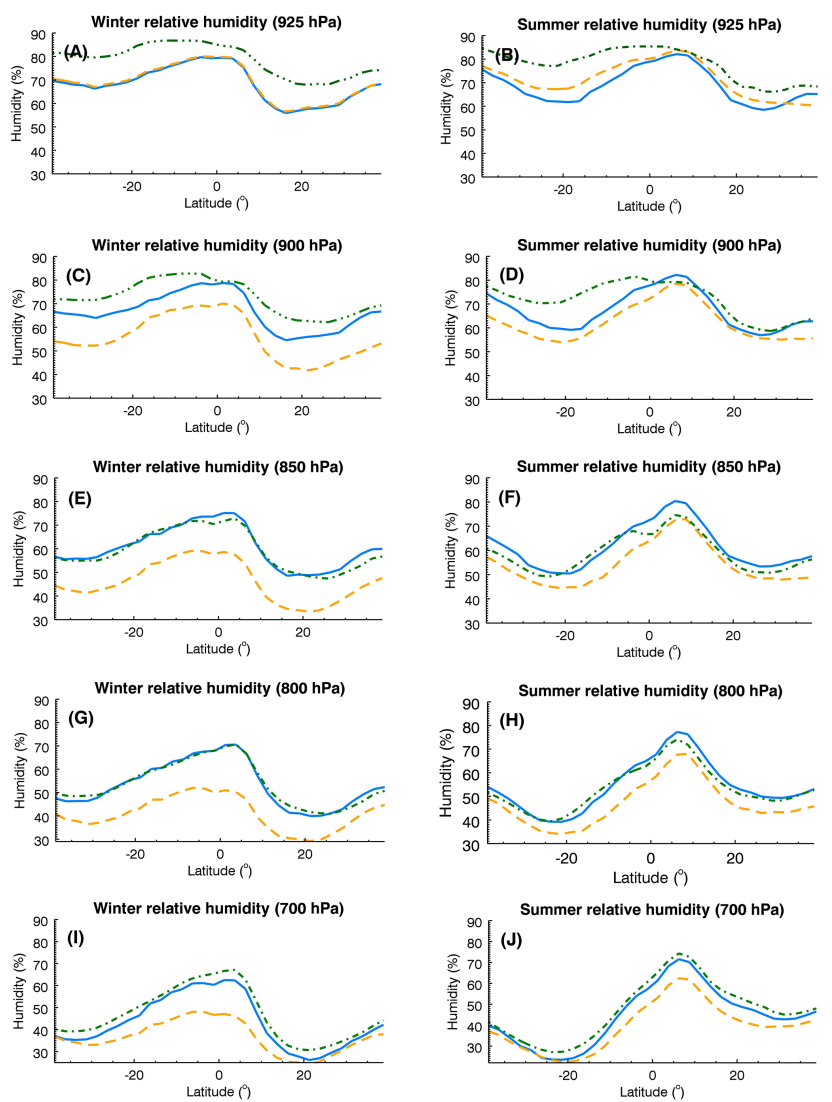

GPSRO (solid blue)

MERRA (dashed dot green)

ECMWF (dashed orange)

Figure 2. Boundary-layer zonal-mean moisture climatology during winter (DJF; left column) and summer (JJA; right column), averaged over the 2007-2009 period from GPSRO (solid blue) observations and MERRA (dashed dot green) and ECMWF (dashed orange) reanalyses.

RH retrieval errors. During summer we notice the same behavior, although the RH differences are smaller than the winter season.

Moving higher into the troposphere $(<500 \mathrm{hPa})$, the GPSRO observations and the ECMWF data set capture well the moisture budget of the ITCZ; however, moving northward the GPSRO observations indicate a moister environment than ECMWF. This behavior is again the same during both seasons. Quantitatively, the GPSRO results are in very good agreement with Kursinski and Hajj (2001), who also reported that the NCEP reanalysis captures a wetter ITCZ than the GPS/MET observations by more than $10 \%$ in the summer of 1995. Also, Kishore et al. (2011) showed that the COSMIC observations are moister than those of both the ECMWF (by 3-8\%) and the Japanese 25-Year Reanalysis project (by 2$20 \%)$ in tropical regions $\left( \pm 20^{\circ}\right)$ during the 2006-2009 period. Chou et al. (2009), although conducting their analysis over a small region off the coast of Taiwan, also reported that the NCEP/NCAR reanalysis is more than $30 \%$ moister than the COSMIC observations at the $400-300 \mathrm{hPa}$ pressure layer.
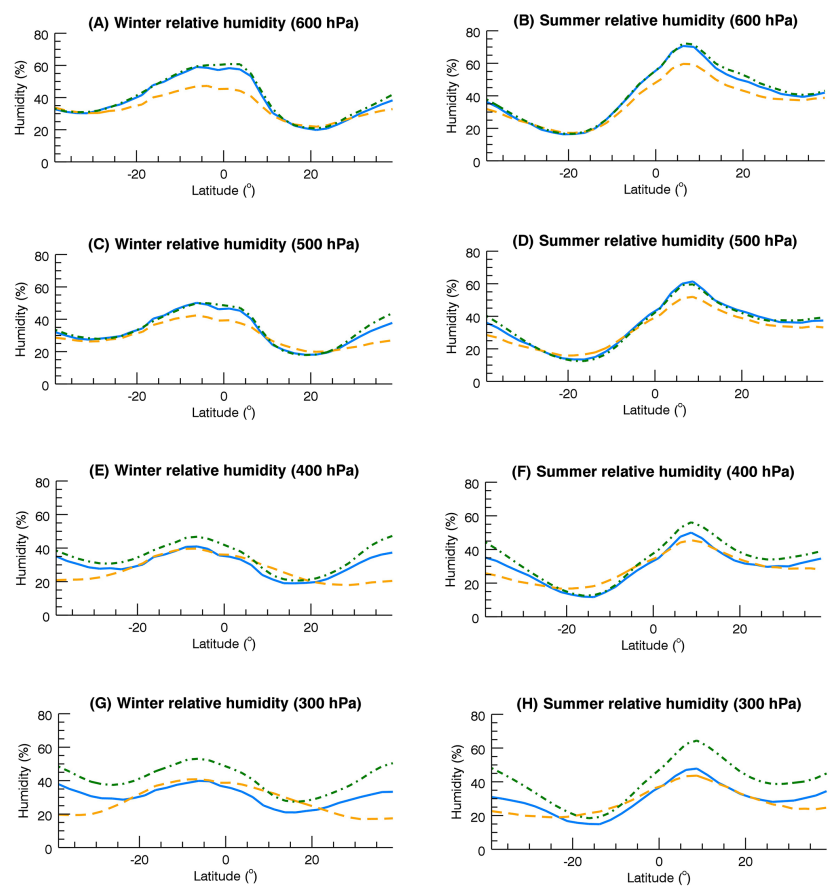

GPSRO (solid blue)

MERRA (dashed dot green)

ECMWF (dashed orange)

Figure 3. Same as Fig. 2 but for the middle-to-upper troposphere.

\subsubsection{Comparing GPSRO observations with MERRA reanalysis}

Relative to MERRA data sets, both during the summer and winter seasons, GPSRO observations show a slightly drier boundary layer at $900 \mathrm{hPa}$, but this dryness quickly disappears at higher altitudes, demonstrating an excellent agreement between the two data sets (cf. Figs. 1-3). Quantitatively, the maximum absolute RH difference is found over the ITCZ at $900 \mathrm{hPa}$ with a value of $\sim 15 \%$ but decreases significantly down to less than $3 \%$ aloft. The magnitude of the reported differences is smaller than the GPSRO RH retrieval errors, marking an excellent agreement between MERRA and GPSRO across the entire tropical region, which is statistically significant to the $95 \%$ confidence level. In the middle troposphere, between $700 \mathrm{hPa}$ and $400 \mathrm{hPa}$, GPSRO and MERRA data sets show again an excellent agreement: the magnitude of the RH differences has a value of less than $3 \%$ at all latitudes.

At $400 \mathrm{hPa}$ we start noticing that GPSRO observations are drier than the MERRA data sets by $5 \%$. This dryness increases to $15 \%$ at $300 \mathrm{hPa}$ over the ITCZ and the rest of the tropical region. Such discrepancies are shown in both seasons. Despite the quantitative differences of the RH in the upper troposphere, GPSRO and MERRA data sets are qualitatively in excellent agreement as they both capture the spatial variability of the RH in both hemispheres. 

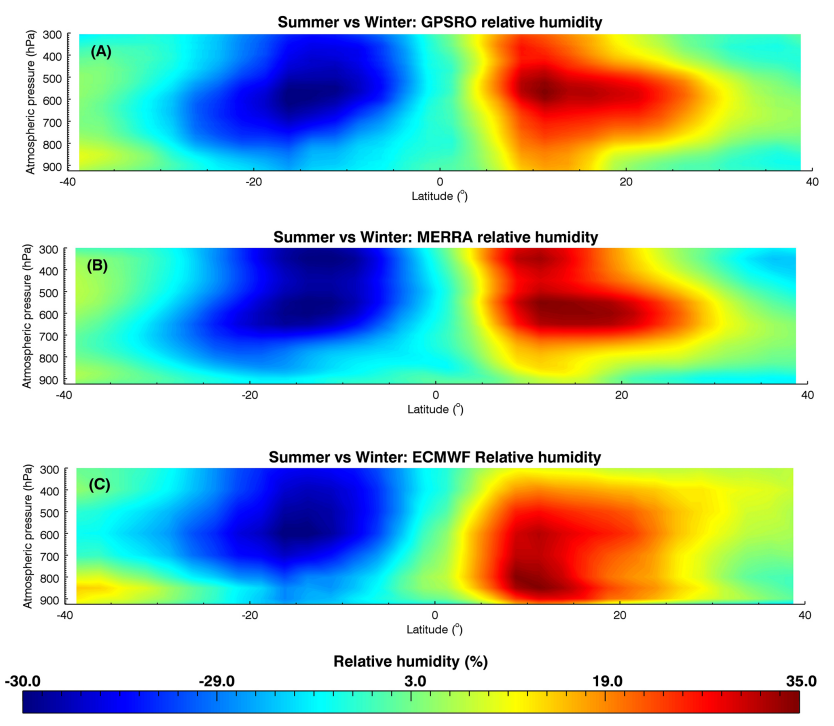

Figure 4. Pressure-latitude cross sections of seasonal variability (summer versus winter) of the relative humidity climatology averaged over the 2007-2009 period using (a) GPSRO observations and (b) MERRA and (c) ECMWF reanalyses.

\subsection{Diagnosing the seasonal variability of relative humidity from GPSRO observations}

Previous studies by Su et al. (2014), Fasullo and Trenberth (2012), and Hall and Qu (2006) highlighted the fact that seasonal variations of $\mathrm{RH}$ are representative of their relationship under global warming. Hence, it is of first-order importance to cross compare and constrain the present-day seasonal cycle of RH among different data sets in order to advance our knowledge of the behavior of the Earth's energy and humidity climatology in future climate projections. Figure 4 shows the seasonal RH variability as the difference between the summer and winter climatologies derived in Sect. 3.1, separately for each data set. Qualitatively, all data sets match up remarkably well, capturing the same spatial patterns.

Current analysis indicates that the middle troposphere (700-500 hPa) centered at $\pm 5-25^{\circ}$ in both hemispheres shows the maximum RH seasonal differences, indicating that it is the most sensitive region to seasonal variations. Quantitatively, both GPSRO observations and MERRA data sets show RH differences of -30 (Southern Hemisphere) and $+36 \%$ (Northern Hemisphere), whereas the ECMWF reanalysis differences range between -22 (Southern Hemisphere) and $+28 \%$ (Northern Hemisphere). Quantitatively, our estimated differences from GPSRO, MERRA, and ECMWF are in very close agreement with recently published research using the latest AIRS (v. 6) observations (Ruzmaikin et al., 2014), which reported equatorial RH fluctuations of $\sim 30 \%$. Although GPSRO observations and MERRA reanalysis show the same range of RH seasonal
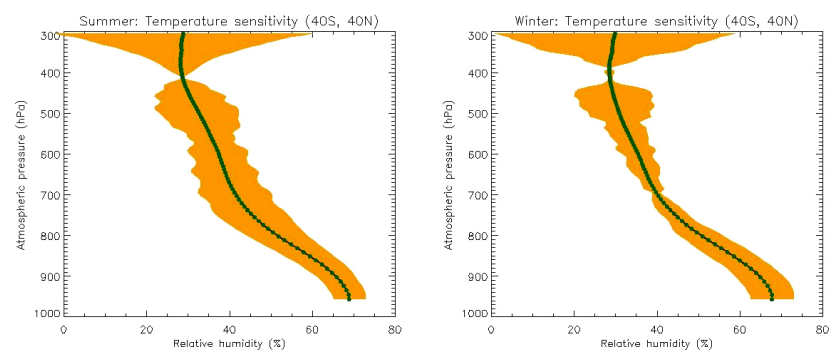

Figure 5. GPSRO RH sensitivity error analysis on $\pm 1.0 \mathrm{~K}$ temperature uncertainty for summer (left) and winter (right), using 1 year of data from 2007, as a function of pressure level. The orange shaded region shows the boundaries of the errors.

variations, the ECMWF reanalysis presents a weaker seasonal variability by about $10 \%$.

Over the ITCZ, around the equatorial belt, all data sets indicate that $\mathrm{RH}$ varies the least between winter and summer throughout the vertical extent of the troposphere. We report RH differences from GPSRO observations and ECMWF and MERRA reanalyses of the order of $\sim 3-5 \%, \sim 3-7 \%$, and $\sim 2-9 \%$, respectively. All data sets agree on the magnitude of the seasonal variations of $\mathrm{RH}$, whereas their small range implies that ITCZ climatology is not as sensitive to seasonal cycles, unlike the middle troposphere inside the dry subsidence regions of the Hadley Cell circulation.

\subsection{Error characterization of the GPSRO humidity on temperature uncertainty}

The percentage error of the GPSRO-derived RH profiles, due to temperature errors, at a certain pressure level is mathematically expressed as (after accounting Eqs. $(2,3)$ ), and is shown in Fig. 5 as a function of pressure level:

$$
\begin{aligned}
& \frac{\delta \mathrm{RH}}{\mathrm{RH}}=\frac{\left(\frac{\partial \mathrm{RH}}{\partial T}\right)}{\mathrm{RH}} \cdot \delta T \Leftrightarrow \frac{e}{e_{\mathrm{S}}} \\
& {\left[\frac{2 N T}{b \cdot e_{\mathrm{S}}}-\frac{a P}{b \cdot e_{\mathrm{S}}}-\frac{4.284 \times 10^{3} \cdot T^{2} \cdot\left(N-\frac{a P}{T}\right)}{b \cdot e_{\mathrm{S}}(T-30.14)^{2}}\right] \cdot \frac{\delta T}{\mathrm{RH}} .}
\end{aligned}
$$

In Fig. 5, we have used 1 year of data (summer and winter 2007) and have assumed a temperature error of $\pm 1.0 \mathrm{~K}$ at all pressure levels and latitudes. The results indicate that the RH error increases with increasing altitude due to the decreasing water vapor concentration (and consequently its contribution to the atmospheric refractivity). Quantitatively, the RH error obtains a value smaller than $5 \%$ in the lower troposphere and smaller than $9 \%$ in the middle troposphere. These results are also in a very good agreement with Vergados et al. (2014), who estimated a $<3$ and $<8 \%$ GPSRO RH retrieval error in the lower and middle troposphere with respect to collocated radiosondes at $\pm 30^{\circ}$, respectively, for a temperature error of $\pm 1.0 \mathrm{~K}$. Above $400 \mathrm{hPa}$, Fig. 5 shows an increase of the RH error up to $30 \%$ at $300 \mathrm{hPa}$. 
The magnitude of the retrieval error in the lower and middle troposphere is smaller than the reported differences between the GPSRO and ECMWF reanalyses in Sect. 3, marking the statistical significance of the observed discrepancies within the boundary layer and above. However, in the upper troposphere the retrieval error grows larger than the documented GPSRO and ECMWF differences, and consequently we can not derive a statistically significant conclusion about the observed discrepancies.

\section{Discussion and conclusions}

Figures 1-3 show that MERRA reanalysis and GPSRO observations are in excellent agreement when capturing the tropical humidity climatology, both qualitatively and quantitatively, in the lower and middle troposphere. Excluding pressure layers below $900 \mathrm{hPa}$ and above $400 \mathrm{hPa}$ (where the atmospheric conditions render the GPSRO-derived RH fields less accurate), the Pearson correlation coefficient between the two data sets for both seasons is greater than 0.80 at the $95 \%$ confidence level based on the Student $t$ test statistics. In the upper troposphere, the observations suggest a drier environment than MERRA by $\sim 15 \%$. Most importantly, these two data sets are independent, as MERRA does not assimilate any GPSRO product; hence, their degree of correlation and statistical differences is a strong indicator of the quality of the GPSRO-derived RH climatology.

Figures 1-3 show that the ECMWF reanalysis is systematically drier than the GPSRO observations throughout the vertical extent of the troposphere, although this disagreement becomes smaller closer to the upper troposphere. The maximum differences are found over the ITCZ location and can reach up to $30 \%$, suggesting that ECMWF underestimates the moisture budget of the ascending branch of the Hadley Cell circulation. Northward from the ITCZ and at higher altitudes, the disagreement between the two data sets diminishes and falls within the estimated GPSRO RH uncertainty errors (e.g., Vergados et al., 2014; Kursinski and Gebhardt, 2014), thus becoming statistically insignificant. In the upper troposphere, both ECMWF and GPSRO data sets capture properly the moisture budget of the ITCZ, although we start noticing small RH differences within the dry subsiding regions northward from the ITCZ.

Figure 1 demonstrates that both MERRA and GPSRO data sets capture the same strength of the winter and summer large-scale atmospheric ascent, which hydrates the middle and the upper troposphere, markedly noticeable over the ITCZ. During summer, we observe a sharper and more organized convection than during winter. Although ECMWF is qualitatively similar to MERRA and GPSRO data sets during summer, it underestimates the strength of hydration during winter. Based on the theory of Huang et al. (2006) and John and Soden (2007) that the vertical transport of moisture from the lower to the upper troposphere (mainly due to deep convection) should be responsible for the documented model discrepancies, we conclude that GPSRO captures stronger convection than ECMWF.

Figure 4 shows that at seasonal timescales GPSRO observations and MERRA and ECMWF reanalyses capture the same RH patterns, and the middle troposphere over the regions of dry air subsidence (cf. Figs. 1 and 4) is most sensitive to seasonal oscillations. The GPSRO and MERRA data sets show an excellent agreement in capturing the magnitude of the seasonal variability of RH; however, ECMWF shows a weaker seasonal oscillation by $\sim 10 \%$.

Finally, we must clarify that during summer (JJA) in 2007, 2008, and 2009, the El Niño-Southern Oscillation (ENSO) index was $<0.4$ (in absolute value). We had a weak El Niño event in the winter (DJF) of 2006-2007 (+0.7), a moderate La Niña in the winter of 2007-2008 (-1.5), and a weak La Niña during the winter of 2008-2009 (-0.8). For reference, the ENSO index time series from 1950 to present fluctuates within the $[-3,3]$ range (http://www.esrl.noaa.gov/psd/enso/ $\mathrm{mei} /$ ). Hence, although ENSO is contained in all data sets, there is no strong forcing present. Such a natural variability affects the Earth's temperature field throughout the vertical extent of the troposphere and stratosphere (Randel et al., 2009), when not higher up, at all latitudinal belts. Additionally, GPSRO observations' unprecedented vertical resolution and global coverage provides a more detailed picture of the tropical 3-D thermal structure than MERRA and ECMWF reanalyses. Consequently, one could argue that the GPSRO observations might better capture the ENSO signal than the ECMWF and MERRA reanalyses. To date, numerous studies have demonstrated GPSRO observations' potential of capturing such a natural variability (Lackner et al., 2011; Steiner et al., 2011; Scherllin-Pirscher et al., 2012).

Acknowledgements. This research was carried out at the Jet Propulsion Laboratory, California Institute of Technology, under a contract with the National Aeronautics and Space Administration. We thank the Giovanni Interactive Visualization and Analysis project for making publicly available the MERRA data sets and the University Corporation for Atmospheric Research (UCAR) for providing the COSMIC and ECMWF data sets. We would like to thank the associate editor and the two anonymous reviews, whose critical evaluation of our manuscript helped us strengthen our results.

Edited by: U. Foelsche 


\section{References}

Boyle, J. and Klein, S. A.: Impact of horizontal resolution on climate model forecasts of tropical precipitation and diabatic heating for the TWP-ICE period, J. Geophys. Res., 115, D23113, doi:10.1029/2010JD014262, 2010.

Carlowicz, M.,: Scientists need better tools to measure water vapor, EOS Trans. AGU, 77, p. 11, doi:10.1029/95EO00011, 1996.

Chen, J., Del Genio, A. D., Carlson, B. E., and Bosilovich, M. G.: The spatiotemporal structure of twentieth-century climate variations in observations and reanalyses, Part I: Long-term trend, J. Climate, 21, 2611-2633, doi:10.1175/2007JCLI2011.1, 2008.

Chou, M.-D., Weng, C.-H., and Lin, P.-H: Analyses of FORMOSAT-3/COSMIC humidity retrievals and comparisons with AIRS retrievals and NCEP/NCAR reanalyses, J. Geophys. Res., 114, D00G03, doi:10.1029/2008JD010227, 2009.

Dai, A.: Precipitation characteristics in eighteen coupled climate models, J. Climate, 19, 4605-4630, doi:10.1175/JCLI3884.1, 2006.

Divakarla, M. G., Barnet, C. D., Goldberg, M. D., McMillin, L. M., Maddy, E., Wolf, W., Zhou, L., and Liu, X.: Validation of atmospheric infrared sounder temperature and water vapor retrievals with matched radiosonde measurements and forecasts, J. Geophys. Res., 111, D09S15, doi:10.1029/2005JD006116, 2006.

Fasullo, J. T. and Trenberth, K. E.: A less cloudy future: the role of subtropical subsidence in climate sensitivity, Science, 338, 792794, doi:10.1126/science.1227465, 2012.

Frenkel, Y., Majda, A. J., and Khouider, B.: Using the stochastic multicloud model to improve tropical convective parameterization: a paradigm example, J. Atmos. Sci., 69, 1080-1105, 2012.

Gorbunov, M. E. and Kornblueh, L.: Analysis and validation of GPS/MET radio occultation data, J. Geophys. Res., 106, 1716117169, 2001.

Gorbunov, M. E., Shmakov, A. V., Leroy, S. S., and Lauritsen, K. B.: COSMIC radio occultation processing: cross-center comparison and validation, J. Atmos. Ocean. Tech., 28, 737-751, doi:10.1175/2011JTECHA1489.1, 2011.

Hajj, G. A., Kursinski, E. R., Romans, L. J., Bertiger, W. I., and Leroy, S. S.: A technical description of atmospheric sounding by GPS occultation, J. Atmos. Sol.-Terr. Phys., 64, 451-469, doi:10.1016/S1364-6826(01)00114-6, 2002.

Hannay, C., Williamson, D. L., Hack, J. J., Kiehl, J. T., Olson, J. G., Klein, S. A., Bretherton, C. S., and Köhler, M.: Evaluation of forecasted southeast Pacific stratocumulus in the NCAR, GFDL, and ECMWF models, J. Climate, 22, 2871-2889, doi:10.1175/2008JCLI2479.1, 2009.

Heise, S., Wickert, J., Beyerle, G., Schmidt, T., and Reigber, C.: Global monitoring of tropospheric water vapor with GPS radio occultation aboard CHAMP, Adv. Space Res., 37, 2222-2227, doi:10.1016/j.asr.2005.06.066, 2006.

Ho, S.-P., Kuo, Y.-H., and Sokolovskiy, S.: Improvement of the temperature and moisture retrievals in the lower troposphere using AIRS and GPS radio occultation measurements, J. Atmos. Ocean. Tech., 24, 1726-1737, doi:10.1175/JTECH2071.1, 2007.

Ho, S.-P., Kirchengast, G., Leroy, S., Wickert, J., Mannucci, A. J., Steiner, A., Hunt, D., Schreiner, W., Sokolovskiy, S., Ao, C., Borsche, M., von Engeln, A., Foelsche, U., Heise, S., Iijima, B., Kuo, Y.-H., Kursinski, R., Pirscher, B., Ringer, M., Rocken, C., and Schmidt, T.: Estimating the uncertainty of using GPS radio occultation data for climate monitoring: intercomparison of CHAMP refractivity climate records from 2002 to 2006 from different data centers, J. Geophys. Res., 114, D23107, doi:10.1029/2009JD011969, 2009.

Ho, S.-P., Zhou, X., Kuo, Y.-H., Hunt, D., and Wang, J.-H.: Global evaluation of radiosonde water vapor systematic biases using GPS radio occultation from COSMIC and ECMWF analysis, Remote Sens., 2, 1320-1330, doi:10.3390/rs2051320, 2010.

Holloway, C. E. and Neelin, J. D.: Moisture vertical structure, column water vapor, and tropical deep convection, J. Atmos. Sci., 66, 1665-1683, doi:10.1175/2008JAS2806.1, 2009.

Huang, X., Ramaswamy, V., and Schwarzkopf, M. D.: Quantification of the source of errors in AM2 simulated tropical clear-sky outgoing longwave radiation, J. Geophys. Res., 111, D14107, doi:10.1029/2005JD006576, 2006.

Jiang, J. H., Su, H., Zhai, C., Perun, V. S., Del Genio, A., Nazarenko, L. S., Donner, L. J., Horowitz, L., Seman, C., Cole, J., Gettelman, A., Ringer, M. A., Rotstayn, L., Jeffrey, S., Wu, T., Brient, F., Dufresne, J.-L., Kawai, H., Koshiro, T., Watanabe, M., Lécuyer, T. S., Volodin, E. M., Iversen, T., Drange, H., Mesquita, M. D. S., Read, W. G., Waters, J. W., Tian, B., Teixeira, J., and Stephens, G. L.: Evaluation of cloud and water vapor simulations in IPCC AR5 688 climate models using NASA "A-Train" satellite observations, J. Geophys. Res., 117, D14105, doi:10.1029/2011JD017237, 2012.

John, V. O. and Soden, B. J.: Temperature and humidity biases in global climate models and their impact on climate feedbacks, Geophys. Res. Lett., 34, L18704, doi:10.1029/2007GL030429, 2007.

Kishore, P., Venkat Ratnam, M., Namboothiri, S. P., Velicogna, I., Basha, G., Jiang, J. H., Igarashi, K., Rao, S. V. B., and Sivakumar, V.: Global $\left(50^{\circ} \mathrm{S}-50^{\circ} \mathrm{N}\right)$ distribution of water vapor observed by COSMIC GPS RO: comparison with GPS radiosonde, NCEP, ERA Interim, and JRA-25 reanalysis datasets, J. Atmos. Sol.-Terr. Phy., 73, 1849-1860, 2011.

Kursinski, E. R. and Hajj, G. A.: A comparison of water vapor derived from GPS occultations and global weather analyses, J. Geophys. Res., 106, 1113-1138, doi:10.1029/2000JD900421, 2001.

Kursinski, E. R., Hajj, G. A., Leroy, S. S., and Herman, B.: The GPS radio occultation technique, Terr. Atmos. Ocean. Sci., 11, 53-114, 2000.

Kursinski, E. R., Hajj, G. A., Schofield, J. T., Linfield, R. P., and Hardy, K. R.: Observing Earth's atmosphere with radio occultation measurements using the Global Positioning System, J. Geophys. Res., 102, 23429-23465, doi:10.1029/97JD01569, 1997.

Kursinski, E. R., Hajj, G. A., Leroy, S. S., and Herman, B.: The GPS radio occultation technique, Terr. Atmos. Ocean. Sci., 11, 53-114, 2000.

Lackner, B. C., Steiner, A. K., Hegerl, G. C., and Kirchengast, G.: Atmospheric climate change detection by radio occultation data using a fingerprinting method, J. Climate, 24, 5275-5291, doi:10.1175/2011JCLI3966.1, 2011.

Lin, Y., Donner, L. J., Petch, J., Bechtold, P., Boyle, J., Klein, S. A., Komori, T., Wapler, K., Willett, M., Xie, X., Zhao, M., Xie, S., McFarlane, S. A., and Schumacher, C.: TWP-ICE global atmospheric model intercomparison: convection responsiveness and resolution impact, J. Geophys. Res., 117, D09111, doi:10.1029/2011JD017018, 2012.

Read, W. G., Lambert, A., Bacmeister, J., Cofield, R. E., Christensen, L. E., Cuddy, D. T., Daffer, W. H., Drouin, B. J., Fet- 
zer, E., Froidevaux, L., Fuller, R., Herman, R., Jarnot, R. F., Jiang, J. H., Jiang, Y. B., Kelly, K., Knosp, B. W., Kovalenko, L. J., Livesey, N. J., Liu, H.-C., Manney, G. L., Pickett, H. M., Pumphrey, H. C., Rosenlof, K. H., Sabounchi, X., Santee, M. L., Schwartz, M. J., Snyder, W. V., Stek, P. C., Su, H., Takacs, L. L., Thurstans, R. P., Vömel, H., Wagner, P. A., Waters, J. W., Webster, C. R., Weinstock, E. M., and Wu, D. L.: Aura Microwave Limb Sounder upper tropospheric and lower stratospheric $\mathrm{H}_{2} \mathrm{O}$ and relative humidity with respect to ice validation, J. Geophys. Res., 112, D24S35, doi:10.1029/2007JD008752, 2007.

Rienecker, M. M., Suarez, M. J., Todling, R., Bacmeister, J., Takacs, L., Liu, H.-C., Gu, W., Sienkiewicz, M., Koster, R. D., Gelaro, R., Stajner, I., and Nielsen, J. E.: The GOES-5 Data Assimilation System - Documentation of versions 5.0.1, 5.1.0, and 5.2.0, NASA Tech. Rep., Series on Global Modeling and Data Assimilation, NASA/TM-2008-104606, 27, 92 pp., 2008.

Rienecker, M. M., Suarez, M. J., Gelaro, R., Todling, R., Bacmeister, J., Liu, E., Bosilovich, M. G., Schubert, S. D., Takacs, L., Kim, G.-K., Bloom, S., Chen, J., Collins, D., Conaty, A., da Silva, A., Gu, W., Joiner, J., Koster, R. D., Lucchesi, R., Molod, A., Owens, T., Pawson, S., Pegion, P., Redder, C. R., Reichle, R., Robertson, F. R., Ruddick, A. G., Sienkiewicz, M., and Woollen, J.: MERRA: NASA's Modern-Era Retrospective Analysis for Research and Applications, J. Climate, 24, 3624-3648, doi:10.1175/JCLI-D-11-00015.1, 2011.

Rocken, C., Anthes, R., Exner, M., Hunt, D., Sokolovskiy, S., Ware, R., Gorbunov, M., Schreiner, W., Feng, D., Herman, B., Kuo, Y.-H., and Zou, X.: Analysis and validation of GPS/MET data in the neutral atmosphere, J. Geophys. Res., 102, 29849-29866, doi:10.1029/97JD02400, 1997.

Ruzmaikin, A., Aumann, H. H., and Manning, E. M.: Relative humidity in the troposphere with AIRS, J. Atmos. Sci., 71, 25162533, doi:10.1175/JAS-D-13-0363.1, 2014.

Scherllin-Pirscher, B., Deser, C., Ho, S.-P., Chou, C., Randel, W., and Kuo, Y.-H.: The vertical and spatial structure of ENSO in the upper troposphere and lower stratosphere from GPS radio occultation measurements, Geophys. Res. Lett., 39, L20801, doi:10.1029/2012GL053071, 2012.

Schmidt, T., Heise, S., Wickert, J., Beyerle, G., and Reigber, C.: GPS radio occultation with CHAMP and SAC-C: global monitoring of thermal tropopause parameters, Atmos. Chem. Phys., 5, 1473-1488, doi:10.5194/acp-5-1473-2005, 2005.
Schreiner, W., Rocken, C., Sokolovskiy, S., Syndergaard, S., and Hunt, D.: Estimates of the precision of GPS radio occultations from the COSMIC/FORMOSAT-3 mission, Geophys. Res. Lett., 34, L04808, doi:10.1029/2006GL027557, 2007.

Simmons, A. J. and Hollingsworth, A.: Some aspects of the improvement in skill of numerical prediction, Q. J. Roy. Meteor Soc., 128, 647-677, 2002.

Simmons, A. J., Hortal, M., Kelly, G., McNally, A., Untach, A., and Uppala, S.: ECMWF analyses and forecasts of stratospheric winter polar vortex breakup: September 2002 in the Southern Hemisphere and related events, J. Atmos. Sci., 62, 668-689, 2005.

Smith, E. and Weintraub, S.: The constants in the equation for atmospheric refractive index at radio frequencies, P. IRE, 41, 10351037, 1953.

Steiner, A. K., Kirchengast, G., and Ladreiter, H. P.: Inversion, error analysis, and validation of GPS/MET occultation data, Ann. Geophys., 17, 122-138, doi:10.1007/s00585-999-0122-5, 1999.

Steiner, A. K., Lackner, B. C., Ladstädter, Scherllin-Pirscher, F. B., Foelsche, U., and Kirchengast, G.: GPS radio occultation for climate monitoring and change detection, Radio Sci., 46, RS0D24, doi:10.1029/2010RS004614, 2011.

Sun, B., Reale, A., Seidel, D. J., and Hunt, D. C.: Comparing radiosonde and COSMIC atmospheric profile data to quantify differences among radiosonde types and the effects of imperfect collocation on comparison statistics, J. Geophys. Res., 115, D23104, doi:10.1029/2010JD014457, 2010.

Tompkins, A. M. and Emanuel, K. A.: The vertical resolution sensitivity of simulated equilibrium temperature and water-vapour profiles, Q. J. Roy. Meteor. Soc., 126, 1219-1238, 2000.

Vergados, P., Mannucci, A. J., and Ao, C. O.: Assessing the performance of GPS radio occultation measurements in retrieving tropospheric humidity in cloudiness: A comparison study with radiosondes, ERA-Interim, and AIRS data sets, J. Geophys. Res.Atmos., 119, 7718-7731, doi:10.1002/2013JD021398, 2014.

Wang, B.-R., Liu, X.-Y., and Wang, J.-K.: Assessment of COSMIC radio occultation retrieval product using global radiosonde data, Atmos. Meas. Tech., 6, 1073-1083, doi:10.5194/amt-6-10732013, 2013.

Weckwerth, T. M., Wulfmeyer, V., Wakimoto, R. M., Michael Hardesty, R., Wilson, J. W., and Banta, R. M.: NCAR-NOAA lower tropospheric water vapor workshop, B. Am. Meteorol. Soc., 80, 2339-2357, 1999. 